\title{
Pemarasitan Benalu Dendrophthoe pentandra (L.) Miq. pada Tanaman Koleksi Kebun Raya Cibodas, Jawa Barat
}

\author{
Sunaryo \\ Bidang Botani, Puslit Biologi - LIPI, Cibinong Jl. Raya Jakarta-Bogor km 46, Cibinong 16911
}

Diterima 14-06-2008 Disetujui 08-10-2008

\begin{abstract}
The mistletoes of Dendrophthoe pentandra (Loranthaceae) grow as parasite on several plant collections of Cibodas Botanical Gardens. Plant collections which attacked by mistletoe are Ficus type (Moraceae), and by individual in number at most is Syzygium racemosum (Myrtaceae). 299 infected and uninfected branches of 67 host species were observed. The results showed that the host branches can be destroyed by mistletoe. Moreover, in the natural conditions, the mistletoe causes degraded of the distal part of the infected branches.
\end{abstract}

Keywords: Cibodas Botanical Gardens, destructions, Dendrophthoe pentandra, host plants,, mistletoe

\section{PENDAHULUAN}

Kebun Raya Cibodas yang terletak di daerah Jawa Barat merupakan salah satu Kebun Raya di Indonesia yang dirancang untuk penanaman koleksi tumbuhan yang berasal dari dataran tinggi dan beriklim basah. Kebun Raya ini terletak di lereng Gunung GedePangrango pada ketinggian $1.425 \mathrm{~m}$ di atas permukaan laut. Luasnya mencapai 125 hektar dan 30\% di antaranya merupakan area yang dihutankan. Jumlah tanaman koleksinya mencapai 1189 jenis yang terdiri atas 183 suku dan 622 marga (Immamudin dkk, 2005).

Sebagai areal konservasi ex-situ yang di dalamnya terdapat koleksi hidup berbagai jenis tumbuhan, Kebun Raya juga merupakan salah suatu ekosistem dimana penyebaran jenis-jenis tumbuhan pemarasit, khususnya benalu, bisa terjadi. Keberadaan benalu sebagai salah satu kelompok tumbuhan tingkat tinggi yang kurang mendapat perhatian. Identifikasi, inventarisasi, maupun pencatatan benalu sebagai bagian penting dari kekayaan koleksi Kebun Raya tidak pernah dilakukan. Hal tersebut disebabkan oleh kehadiran benalu sering tidak terpantau, sementara keberadaannya di suatu areal tidak bersifat permanen/ menetap. Di suatu saat benalu dapat memarasiti jenisjenis pohon, tetapi di saat lain akan menghilang seiring

Telp: 08121100047

E-mail: herbogor@indo.net.id dengan matinya/dipangkasnya bagian-bagian cabang/ ranting yang diparasitinya. Hal lain yang harus mendapat perhatian terhadap benalu adalah sifat parasitismenya yang dapat mengganggu bahkan merusak tumbuhan inangnya.

Berdasarkan studi pustaka untuk jenis-jenis benalu pemarasit di Jawa Barat ditemukan 28 jenis benalu yang masuk kedalam suku Loranthaceae dan Viscaceae, dan 22 jenis di antaranya dapat tumbuh pada ketinggian $>1300 \mathrm{~m}$ di atas permukaan laut (Backer \& Bakhuizen van den Brink, 1965). Sedangkan identifikasi dan karakterisasi tumbuhan benalu yang dilakukan oleh $\mathrm{Uji}$ \& Sunaryo (dalam editing) di Kebun Raya Cibodas berhasil ditemukan lima jenis benalu. Kelima jenis benalu tersebut adalah: Dendrophthoe pentandra (L.) Miq., Scurrula oortiana (Korth.) Danser, Macrosolen cochinchinensis (Lour.) Tiegh., Leopeostegeres gemmiflorus (Blume) dan Viscum articulatum Burm.f.. Di antara kelima jenis benalu tersebut, benalu $D$. Pentandra adalah jenis benalu yang paling banyak menyerang tumbuhan koleksi di Kebun Raya Cibodas.

$D$. pentandra merupakan jenis benalu yang masuk dalam suku Loranthaceae. $D$. pentandra ditemukan di daerah hutan hujan atau di hutan yang terbuka, di perkebunan, di taman-taman kota, hingga di sekitar pemukiman penduduk. Penyebarannya terjadi melalui burung-burung pemakan bijinya. Kemampuan benalu ini tidak hanya menyerang jenis tumbuhan inang 
tertentu melainkan dapat memarasit berbagai jenis tumbuhan inang, baik berupa semak ataupun pohon, selama beberapa tahun. $D$. pentandra dapat hidup pada jenis-jenis tumbuhan yang beragam serta rentang sebaran ekologis yang cukup luas.

Sebagai jenis tumbuhan parasit keberadaan benalu $D$. pentandra sering mengindikasikan terjadinya gangguan ataupun kerusakan tumbuh-tumbuhan inang yang diparasitinya, apalagi bila keberadaannya dalam jumlah yang bany ak (Sunaryo 1998). Adapun tujuan penelitian ini adalah mencatat jenis-jenis tumbuhan koleksi di Kebun Raya Cibodas yang diparasiti oleh benalu $D$. pentandra serta mengukur gangguan yang ditimbulkannya.

\section{BAHAN DAN METODE}

Identifikasi jenis benalu. Penjelajahan di lokasi Kebun Raya Cibodas dilakukan untuk mendapatkan spesimen tumbuhan benalu. Dengan metode jelajah ini (Balgooy 1987; Rugayah et al, 2004) setiap benalu yang ditemukan diidentifikasi benalu dan tumbuhan inangnya. Pencatatan dilakukan terhadap setiap ciriciri morfologinya. Identifikasi benalu menggunakan kunci determinasi yang ada dalam buku Backer \& Bakhuizen van den Brink (1965) dan Barlow (1967). Khusus untuk benalu jenis $D$. pentandra beserta jenis tumbuhan inang yang diparasitinya dilakukan pemisahan data untuk keperluan analisa lebih lanjut.

Identifikasi dampak pemarasitan benalu. Untuk mengidentifikasi dampak pemarasitan benalu pada kerusakan tumbuhan inang maka dilakukan pengukuran-pengukuran pada bagian-bagian cabang/ ranting, baik yang diparasiti maupun bebas parasit, dalam satuan $\mathrm{mm}$. Pengukuran dilakukan terhadap keliling bagian proksimal $(\mathrm{P})$, yaitu bagian cabang/ ranting yang aliran nutrisinya masih belum mengalami gangguan oleh keberadaan benalu, dan keliling bagian distal (D), yaitu bagian cabang/ranting yang sudah mengalami gangguan. Selisih keliling antara bagian proksimal dan distal cabang/ranting terparasiti kemudian dibandingkan dengan selisih keliling bagian proksimal (P1) dan distal (D1) cabang/ranting yang bebas parasit. Perbedaan nilai di antara kedua bagian tersebut yang cukup signifikan merupakan nilai kerusakan pertumbuhan bagian cabang/ranting tumbuhan inang sebagai dampak dari pemarasitan benalu. Pengukuran dilakukan pada setiap cabang/ ranting yang diparasiti benalu. Pada satu individu inang sering terjadi beberapa pemarasitan benalu, sehingga pengukuran juga dilakukan pada cabang-cabang/ ranting-ranting yang terdapat pada individu yang sama (Gambar 1). Apabila bagian distal cabang/ranting yang terparasiti (D) dalam keadaan mati atau kering, yang berarti $\mathrm{D}=0$. Untuk menentukan Nilai Kerusakan (NK) digunakan rumusan seperti dibawah (Sunaryo, dalam editing).

$$
N K(\%)=\frac{P-D}{\left(P_{1}-D_{1}\right)} \times 100 \%
$$

\section{Keterangan:}

$\mathrm{P}=$ Bagian proksimal cabang/ranting diparasiti benalu

$\mathrm{D}=$ Bagian distal cabang/ranting diparasiti benalu

P1 = Bagiang proksimal cabang/ranting bebas benalu

D1 = Bagian distal cabang $/$ ranting bebas benalu

NK $=$ Nilai Kerusakan (dalam \%)

A)
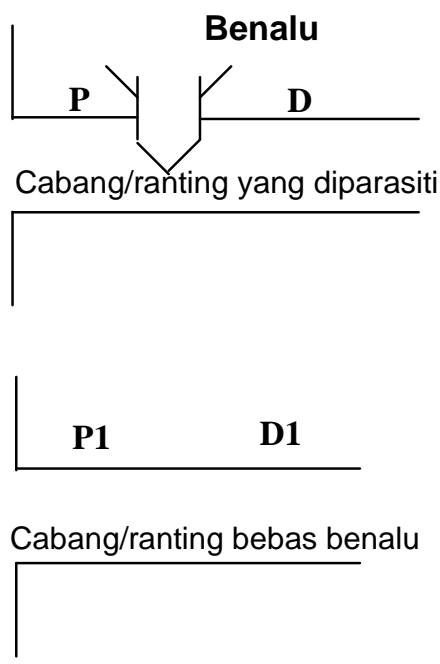

Gambar 1. Skema pengukuran untuk menentukan Nilai Kerusakan (NK): A. Cabang/ranting yang diparasit benalu $D$. Pentandra. B. Cabang/ranting bebas benalu

\section{HASIL DAN PEMBAHASAN}

Benalu Dendrophthoe pentandra dideskripsi sebagai berikut: berupa tumbuhan perdu, bersifat hemiparasit, agak tegar, bercabang banyak, tinggi 0,5-1,5 m. Daun tersebar atau sedikit berhadapan, menjorong, panjang $6-13 \mathrm{~cm}$ dan lebar $1,5-8 \mathrm{~cm}$, pangkal menirus-membaji, ujung tumpul-runcing, panjang tangkai daun 5-20 mm. Perbungaan tandan dengan $6-12$ bunga, panjang sumbu perbungaan 10-35 mm. Bunga dengan 1 braktea di pangkal, 
biseksual, diklamid, kelopak mereduksi; mahkota bunga terdiri atas 5 cuping, di bagian bawah saling berpautan, agak menggelendut, panjang 13-26 mm, menyempit membentuk leher, bagian ujung mengganda, mula-mula hijau kemudian hijau kekuningan sampai kuning orange atau merah orange, panjang tabung 6-12 mm dan menggenta; benang sari 5 , panjang kepala sari $2-5 \mathrm{~mm}$ dan tumpul serta melekat pada bagian pangkal (basifik); putik dengan kepala putik membintul. Buah berbentuk bulat telur, panjang mencapai $10 \mathrm{~mm}$ dengan lebar $6 \mathrm{~mm}$, bila masak kuning jingga. Berbiji 1, biji ditutupi lapisan lengket.

Penyebaran $D$. pentandra meliputi India sampai Indo Cina, Semenanjung Malaya, Sumatera, Jawa, Kalimantan, Nusa Tenggara dan Filipina (Barlow 1967). Habitat tumbuhnya umumnya di hutan hujan atau hutan yang terbuka, di perkebunan-perkebunan dataran rendah, bahkan juga di daerah-daerah pemukiman, namun seringkali terdapat sampai pada ketinggian $1650 \mathrm{~m}$ dpl (Barlow 1967).

Kegunaannya sebagai obat dengan cara membuat bubur dari bagian daun untuk mengobati luka pedih, bernanah dan infeksi pada kulit. Air rebusan semua bagian tumbuhan bila diminum dapat mengobati hipertensi dan apabila dicampur minuman teh digunakan untuk obat batuk (Valkenburg 2003).
Dari hasil penjelajahan yang dilakukan selama 2 minggu (3 s/d 16 Juli 2007) telah diidentifikasi sebanyak 67 jenis tumbuhan koleksi di Kebun Raya Cibodas diparasiti benalu $D$. pentandra. Jenis-jenis tersebut dikelompokkan ke dalam 36 suku (Tabel 1).

Untuk mengidentifikasi gangguan tumbuhan koleksi maka telah dilakukan pengukuran 299 cabang/ ranting dari jenis-jenis tumbuhan yang diparasiti benalu D. pentandra. Di samping pengukuran-pengukuran yang dilakukan pada bagian cabang/ranting inang, juga dilakukan pengukuran pada bagian cabang/ranting inang bebas infeksi sebagai pembandingnya. Hasil pengukuran tersebut dapat dilihat pada Tabel 1 .

Dari hasil pengukuran terlihat adanya hubungan antara besarnya selisih bagian proksimal dan distal cabang/ranting terparasiti dengan Nilai Kerusakan. Semakin besar selisih bagian proksimal dan distal (PD) cabang/ranting terparasiti maka semakin besar pula Nilai Kerusakannya. Nilai tertinggi dari kerusakan cabang/ranting tumbuhan inang terjadi apabila bagian distalnya mengalami kekeringan, mati dan gugur $(D=$ 0 ). Apabila kematian bagian distal cabang/ranting terparasiti dipakai sebagai tolok ukur kerusakan, maka beberapa suku yang mempunyai Nilai Kerusakan tertinggi berturut-turut adalah: Boraginaceae (100\%),

Tabel 1. Jenis tumbuhan yang diparasiti benalu D. pentandra dan hasil pengukuran gangguan yang ditimbulkannya.

\begin{tabular}{|c|c|c|c|c|c|c|c|c|}
\hline \multirow{2}{*}{ No. } & \multirow{2}{*}{$\begin{array}{l}\text { Cabang/ranting jenis dan suku tumbuhan } \\
\text { yang diparasiti benalu } D \text {. pentandra }\end{array}$} & \multicolumn{3}{|c|}{$\begin{array}{l}\text { Cabang/ranting terparasiti } \\
(\mathrm{mm})\end{array}$} & \multicolumn{3}{|c|}{$\begin{array}{c}\text { Cabang/ranting bebas } \\
\text { parasit }(\mathrm{mm})\end{array}$} & \multirow{2}{*}{$\begin{array}{l}\text { NK } \\
(\%)\end{array}$} \\
\hline & & $P$ & $\mathrm{D}$ & P-D & P1 & D1 & P1-D1 & \\
\hline I & ANACARDIACEAE & & & & & & & \\
\hline 1. & Rhus sccedanea L. & 50 & 32 & 18 & 52 & 50 & 2 & 34.6 \\
\hline 2. & Cabang/ranting pada individu yang sama & 59 & 57 & 2 & 60 & 59 & 1 & 3.3 \\
\hline 3. & Cabang/ranting pada individu yang sama & 62 & 55 & 7 & 59 & 58 & 1 & 11.1 \\
\hline 4. & Cabang/ranting pada individu yang sama & 56 & 34 & 22 & 54 & 54 & 0 & 39.3 \\
\hline 5. & Cabang/ranting pada individu yang sama & 47 & 45 & 2 & 49 & 49 & 0 & 4.3 \\
\hline 6. & Schinus terebinthifolius Raddi & 54 & 52 & 2 & 53 & 52 & 1 & 3.6 \\
\hline 7. & Cabang/ranting pada individu yang sama & 64 & 63 & 1 & 65 & 64 & 1 & 1.5 \\
\hline 8. & Cabang/ranting pada individu yang sama & 37 & 33 & 4 & 35 & 34 & 1 & 10.5 \\
\hline 9. & Cabang/ranting pada individu yang sama & 70 & 36 & 34 & 67 & 67 & 0 & 48.6 \\
\hline 10. & Cabang/ranting pada individu yang sama & 77 & 70 & 7 & 80 & 78 & 2 & 8.9 \\
\hline 11. & Cabang/ranting pada individu yang sama & 35 & 0 & 35 & 33 & 32 & 1 & 97.2 \\
\hline 12. & Cabang/ranting pada individu yang sama & 71 & 0 & 71 & 68 & 67 & 1 & 98.6 \\
\hline 13. & Schinus terebinthifolius & 33 & 32 & 1 & 30 & 30 & 0 & 3.0 \\
\hline 14. & Cabang/ranting pada individu yang sama & 58 & 56 & 2 & 57 & 55 & 2 & 3.3 \\
\hline 15. & Cabang/ranting pada individu yang sama & 23 & 22 & 1 & 25 & 24 & 1 & 4.2 \\
\hline II & ANNONACEAE & & & & & & & \\
\hline 16. & Orophea hexandra Blume & 49 & 33 & 6 & 49 & 49 & 0 & 12.2 \\
\hline 17. & Cabang/ranting pada individu yang sama & 24 & 0 & 24 & 22 & 20 & 2 & 92.3 \\
\hline 18. & Cabang/ranting pada individu yang sama & 35 & 0 & 35 & 37 & 36 & 1 & 97.2 \\
\hline
\end{tabular}




\begin{tabular}{|c|c|c|c|c|c|c|c|c|}
\hline \multirow{2}{*}{ No. } & \multirow{2}{*}{$\begin{array}{l}\text { Cabang/ranting jenis dan suku tumbuhan } \\
\text { yang diparasiti benalu } D \text {. pentandra }\end{array}$} & \multicolumn{3}{|c|}{$\begin{array}{l}\text { Cabang/ranting terparasiti } \\
(\mathrm{mm})\end{array}$} & \multicolumn{3}{|c|}{$\begin{array}{c}\text { Cabang/ranting bebas } \\
\text { parasit }(\mathrm{mm})\end{array}$} & \multirow{2}{*}{$\begin{array}{l}\text { NK } \\
(\%)\end{array}$} \\
\hline & & $P$ & $\mathrm{D}$ & P-D & P1 & D1 & P1-D1 & \\
\hline III & APOCYNACEAE & & & & & & & \\
\hline 19. & Rauvolfia javanica Koord. \& Val. & 97 & 95 & 2 & 102 & 100 & 2 & 2.0 \\
\hline 20. & Cabang/ranting pada individu yang sama & 90 & 85 & 5 & 87 & 85 & 2 & 5.4 \\
\hline 21. & Cabang/ranting pada individu yang sama & 66 & 57 & 9 & 63 & 62 & 1 & 13.4 \\
\hline 22. & Cabang/ranting pada individu yang sama & 58 & 43 & 15 & 57 & 57 & 0 & 25.9 \\
\hline IV & ARAUCARIACEAE & & & & & & & \\
\hline 23. & Araucaria bidwilii Hook. & 42 & 39 & 3 & 54 & 53 & 1 & 7.0 \\
\hline V & BORAGINACEAE & & & & & & & \\
\hline 24. & Ehretia javanica Blume & 57 & 0 & 57 & 58 & 56 & 2 & 96.6 \\
\hline 25. & Cabang/ranting pada individu yang sama & 40 & 0 & 40 & 41 & 39 & 2 & 95.2 \\
\hline $\mathrm{VI}$ & CASUARINACEAE & & & & & & & \\
\hline 26. & Casuarina junghuhniana Miq. & 98 & 85 & 13 & 95 & 94 & 1 & 13.1 \\
\hline 27. & Cabang/ranting pada individu yang sama & 71 & 47 & 24 & 73 & 72 & 1 & 33.3 \\
\hline VII & CORNACEAE & & & & & & & \\
\hline 28. & Cornus capitata Wall. & 40 & 19 & 21 & 40 & 40 & 0 & 52.5 \\
\hline VIII & DILLENIACEAE & & & & & & & \\
\hline 29. & Dillenia philippinensis Rolfe & 67 & 63 & 4 & 70 & 68 & 2 & 5.8 \\
\hline 30. & Cabang/ranting pada individu yang sama & 63 & 42 & 21 & 60 & 60 & 0 & 33.3 \\
\hline 31. & Cabang/ranting pada individu yang sama & 59 & 55 & 4 & 56 & 55 & 1 & 6,7 \\
\hline 32. & Cabang/ranting pada individu yang sama & 65 & 49 & 6 & 63 & 63 & 0 & 9.2 \\
\hline 33. & Cabang/ranting pada individu yang sama & 48 & 0 & 48 & 44 & 42 & 2 & 96.0 \\
\hline IX & EBENACEAE & & & & & & & \\
\hline 34. & Diospyros kaki Thunb. & 61 & 32 & 29 & 87 & 87 & 0 & 47.5 \\
\hline 35. & Diospyros kaki & 41 & 34 & 7 & 44 & 44 & 0 & 17.1 \\
\hline 36. & Cabang/ranting pada individu yang sama & 39 & 27 & 12 & 41 & 40 & 1 & 30.0 \\
\hline 37. & Cabang/ranting pada individu yang sama & 28 & 25 & 3 & 26 & 25 & 1 & 10.3 \\
\hline 38. & Diospyros kaki & 87 & 61 & 26 & 60 & 59 & 1 & 29.5 \\
\hline 39. & Cabang/ranting pada individu yang sama & 53 & 49 & 4 & 53 & 53 & 1 & 7.4 \\
\hline 40. & Cabang/ranting pada individu yang sama & 59 & 57 & 2 & 60 & 59 & 1 & 3.3 \\
\hline 41. & Cabang/ranting pada individu yang sama & 95 & 45 & 50 & 90 & 89 & 1 & 52.1 \\
\hline 42. & Cabang/ranting pada individu yang sama & 44 & 33 & 11 & 45 & 44 & 1 & 24.4 \\
\hline 43. & Diospyros kaki & 52 & 32 & 20 & 53 & 53 & 0 & 38.5 \\
\hline 44. & Cabang/ranting pada individu yang sama & 52 & 36 & 16 & 50 & 49 & 1 & 30.2 \\
\hline 45. & Cabang/ranting pada individu yang sama & 79 & 48 & 31 & 81 & 80 & 1 & 38.7 \\
\hline 46. & Cabang/ranting pada individu yang sama & 63 & 31 & 32 & 61 & 61 & 0 & 50.8 \\
\hline 47. & Cabang/ranting pada individu yang sama & 49 & 42 & 7 & 47 & 45 & 2 & 13.7 \\
\hline $\mathrm{X}$ & ELAEOCARPACEAE & & & & & & & \\
\hline 48. & Elaeocarpus oxypyren Koord. & 35 & 0 & 35 & 29 & 28 & 1 & 97.2 \\
\hline 49. & Cabang/ranting pada individu yang sama & 37 & 36 & 1 & 35 & 34 & 1 & 2.6 \\
\hline 50. & Elaeocarpus oxypyren & 62 & 0 & 62 & 81 & 79 & 2 & 96.9 \\
\hline$X I$ & ERICACEAE & & & & & & & \\
\hline 51. & Rhododendron mucronatum (BI.) G. Don. & 37 & 35 & 2 & 37 & 37 & 0 & 5.4 \\
\hline 52. & Cabang/ranting pada individu yang sama & 35 & 18 & 17 & 33 & 31 & 2 & 45.9 \\
\hline XII & EUPHORBIACEAE & & & & & & & \\
\hline 53. & Acalypha wilkesiana Muell. Arg. & 35 & 31 & 4 & 36 & 35 & 1 & 11.1 \\
\hline 54. & Cabang/ranting pada individu yang sama & 25 & 0 & 25 & 22 & 22 & 0 & 100 \\
\hline
\end{tabular}




\begin{tabular}{|c|c|c|c|c|c|c|c|c|}
\hline \multirow{2}{*}{ No. } & \multirow{2}{*}{$\begin{array}{l}\text { Cabang/ranting jenis dan suku tumbuhan } \\
\text { yang diparasiti benalu } D \text {. pentandra }\end{array}$} & \multicolumn{3}{|c|}{$\begin{array}{l}\text { Cabang/ranting terparasiti } \\
(\mathrm{mm})\end{array}$} & \multicolumn{3}{|c|}{$\begin{array}{l}\text { Cabang/ranting bebas } \\
\text { parasit }(\mathrm{mm})\end{array}$} & \multirow{2}{*}{$\begin{array}{l}\text { NK } \\
(\%)\end{array}$} \\
\hline & & $P$ & $\mathrm{D}$ & P-D & P1 & D1 & P1-D1 & \\
\hline 55. & Cabang/ranting pada individu yang sama & 26 & 14 & 12 & 29 & 28 & 1 & 44.4 \\
\hline XIII & FABACEAE & & & & & & & \\
\hline 56. & Erythrina chiapasana & 58 & 21 & 37 & 66 & 66 & 0 & 63.8 \\
\hline 57. & Cabang/ranting pada individu yang sama & 56 & 0 & 56 & 53 & 51 & 2 & 96.5 \\
\hline 58. & Cabang/ranting pada individu yang sama & 54 & 23 & 31 & 56 & 55 & 1 & 56.4 \\
\hline 59. & Erythrina guatemalensis & 15 & 0 & 15 & 14 & 13 & 1 & 93.7 \\
\hline 60. & Erythrina guatemalensis & 46 & 40 & 6 & 49 & 48 & 1 & 12.8 \\
\hline 61. & Gleditsia sinensis & 63 & 42 & 21 & 54 & 52 & 2 & 32.3 \\
\hline 62. & Cabang/ranting pada individu yang sama & 49 & 42 & 7 & 51 & 49 & 2 & 13.7 \\
\hline 63. & Cabang/ranting pada individu yang sama & 64 & 49 & 5 & 62 & 61 & 1 & 7.7 \\
\hline 64. & Cabang/ranting pada individu yang sama & 82 & 0 & 82 & 80 & 79 & 1 & 98.8 \\
\hline XIV & FAGACEAE & & & & & & & \\
\hline 65. & Quercus myrsinaefolia Blume & 56 & 39 & 17 & 54 & 54 & 0 & 30.3 \\
\hline 66. & Cabang/ranting pada individu yang sama & 39 & 24 & 14 & 38 & 37 & 1 & 35.0 \\
\hline 67. & Cabang/ranting pada individu yang sama & 45 & 0 & 45 & 44 & 42 & 2 & 95.7 \\
\hline 68. & Cabang/ranting pada individu yang sama & 34 & 27 & 7 & 30 & 29 & 1 & 20.0 \\
\hline$X V$ & HAMAMELIDACEAE & & & & & & & \\
\hline 69. & Altingia excelsa Noronha & 50 & 0 & 50 & 58 & 57 & 1 & 98.0 \\
\hline 70. & Cabang/ranting pada individu yang sama & 53 & 44 & 9 & 53 & 52 & 1 & 16.7 \\
\hline 71. & Cabang/ranting pada individu yang sama & 61 & 24 & 37 & 58 & 57 & 1 & 59.7 \\
\hline 72. & Altingia excelsa & 31 & 0 & 31 & 33 & 33 & 0 & 100 \\
\hline 73. & Cabang/ranting pada individu yang sama & 34 & 0 & 34 & 32 & 32 & 0 & 100 \\
\hline 74. & Liquidambar formosana Hance & 90 & 82 & 8 & 64 & 62 & 2 & 8.7 \\
\hline 75. & Cabang/ranting pada individu yang sama & 26 & 0 & 26 & 27 & 26 & 1 & 96.3 \\
\hline 76. & Cabang/ranting pada individu yang sama & 19 & 0 & 19 & 22 & 21 & 1 & 95.0 \\
\hline 77. & Cabang/ranting pada individu yang sama & 61 & 49 & 12 & 58 & 57 & 1 & 19.4 \\
\hline $\mathrm{XVI}$ & LAURACEAE & & & & & & & \\
\hline 78. & Cinnamomum camphora (L.) Presl. & 50 & 0 & 50 & 43 & 42 & 1 & 98.0 \\
\hline 79. & Cinnamomum camphora & 24 & 18 & 6 & 28 & 26 & 2 & 23.1 \\
\hline 80. & Cryptocarya ferrea Blume & 49 & 43 & 6 & 50 & 48 & 2 & 11.8 \\
\hline 81. & Cabang/ranting pada individu yang sama & 36 & 15 & 21 & 35 & 34 & 1 & 56.7 \\
\hline 82. & Cabang/ranting pada individu yang sama & 91 & 0 & 91 & 89 & 88 & 1 & 99.0 \\
\hline XVII & LYTHRACEAE & & & & & & & \\
\hline 83. & Lagerstroemia indica L. & 43 & 42 & 1 & 42 & 42 & 0 & 2.3 \\
\hline 84. & Cabang/ranting pada individu yang sama & 37 & 36 & 1 & 39 & 38 & 1 & 2.6 \\
\hline 85. & Cabang/ranting pada individu yang sama & 43 & 0 & 43 & 41 & 40 & 1 & 97.8 \\
\hline 86. & Cabang/ranting pada individu yang sama & 43 & 39 & 4 & 44 & 43 & 1 & 9.1 \\
\hline XVIII & MAGNOLIACEAE & & & & & & & \\
\hline 87. & Magnolia grandiflora L. & 98 & 84 & 14 & 99 & 98 & 1 & 14.1 \\
\hline 88. & Cabang/ranting pada individu yang sama & 19 & 11 & 8 & 20 & 19 & 1 & 40.0 \\
\hline 89. & Cabang/ranting pada individu yang sama & 66 & 39 & 27 & 64 & 63 & 1 & 40.3 \\
\hline 90. & Cabang/ranting pada individu yang sama & 70 & 37 & 33 & 70 & 68 & 2 & 45.8 \\
\hline 91. & Magnolia grandiflora & 62 & 44 & 18 & 73 & 73 & 0 & 29.0 \\
\hline 92. & Cabang/ranting pada individu yang sama & 31 & 28 & 3 & 29 & 29 & 0 & 9.7 \\
\hline 93. & Cabang/ranting pada individu yang sama & 48 & 39 & 9 & 49 & 48 & 1 & 18.4 \\
\hline
\end{tabular}




\begin{tabular}{|c|c|c|c|c|c|c|c|c|}
\hline \multirow{2}{*}{ No. } & \multirow{2}{*}{$\begin{array}{l}\text { Cabang/ranting jenis dan suku tumbuhan } \\
\text { yang diparasiti benalu } D \text {. pentandra }\end{array}$} & \multicolumn{3}{|c|}{$\begin{array}{l}\text { Cabang/ranting terparasiti } \\
(\mathrm{mm})\end{array}$} & \multicolumn{3}{|c|}{$\begin{array}{c}\text { Cabang/ranting bebas } \\
\text { parasit }(\mathrm{mm})\end{array}$} & \multirow{2}{*}{$\begin{array}{l}\text { NK } \\
(\%)\end{array}$} \\
\hline & & $P$ & $\mathrm{D}$ & P-D & $\mathrm{P} 1$ & $\mathrm{D} 1$ & P1-D1 & \\
\hline 94. & Magnolia grandiflora & 88 & 82 & 6 & 63 & 63 & 0 & 6.8 \\
\hline 95. & Cabang/ranting pada individu yang sama & 93 & 84 & 9 & 94 & 93 & 1 & 9.6 \\
\hline 96. & Cabang/ranting pada individu yang sama & 85 & 45 & 40 & 81 & 79 & 2 & 46.0 \\
\hline 97. & Cabang/ranting pada individu yang sama & 50 & 32 & 18 & 47 & 46 & 1 & 35.3 \\
\hline 98. & Cabang/ranting pada individu yang sama & 31 & 29 & 2 & 33 & 33 & 0 & 6.4 \\
\hline 99. & Manglietia glauca Blume & 78 & 72 & 6 & 80 & 79 & 1 & 7.6 \\
\hline 100. & Cabang/ranting pada individu yang sama & 45 & 0 & 45 & 44 & 43 & 1 & 97.8 \\
\hline 101. & Cabang/ranting pada individu yang sama & 82 & 77 & 5 & 80 & 79 & 1 & 6.0 \\
\hline 102. & Cabang/ranting pada individu yang sama & 67 & 0 & 67 & 65 & 64 & 1 & 98.5 \\
\hline 103. & Cabang/ranting pada individu yang sama & 74 & 59 & 15 & 72 & 71 & 1 & 20.0 \\
\hline 104. & Michelia montana Blume & 95 & 0 & 95 & 96 & 95 & 1 & 98.9 \\
\hline $\mathrm{XIX}$ & MIMOSACEAE & & & & & & & \\
\hline 105. & Acacia melanoxylon $\mathrm{R}$. Br. & 52 & 0 & 52 & 51 & 51 & 0 & 100 \\
\hline 106. & Cabang/ranting pada individu yang sama & 37 & 0 & 37 & 38 & 37 & 1 & 97.4 \\
\hline 107. & Calliandra haematocephala Hassk. & 35 & 31 & 4 & 34 & 34 & 0 & 11.4 \\
\hline 108. & Cabang/ranting pada individu yang sama & 20 & 10 & 10 & 19 & 18 & 1 & 47.6 \\
\hline 109. & Cabang/ranting pada individu yang sama & 22 & 8 & 14 & 23 & 22 & 1 & 60.9 \\
\hline 110. & Calliandra calothyrsus Meisn. & 53 & 47 & 6 & 53 & 53 & 0 & 11.3 \\
\hline 111. & Cabang/ranting pada individu yang sama & 39 & 28 & 11 & 50 & 49 & 1 & 27.5 \\
\hline 112. & Cabang/ranting pada individu yang sama & 35 & 34 & 1 & 37 & 36 & 1 & 2.8 \\
\hline 113. & Cabang/ranting pada individu yang sama & 24 & 17 & 7 & 22 & 21 & 1 & 28.0 \\
\hline 114. & Cabang/ranting pada individu yang sama & 21 & 19 & 2 & 19 & 18 & 1 & 9.1 \\
\hline$X X$ & MORACEAE & & & & & & & \\
\hline 115. & Ficus ribes Reinw. ex Blume & 60 & 54 & 6 & 63 & 61 & 2 & 9.7 \\
\hline 116. & Cabang/ranting pada individu yang sama & 37 & 0 & 37 & 39 & 37 & 2 & 9.5 \\
\hline 117. & Cabang/ranting pada individu yang sama & 81 & 79 & 2 & 83 & 82 & 1 & 2.4 \\
\hline 118. & Cabang/ranting pada individu yang sama & 84 & 53 & 31 & 82 & 81 & 1 & 36.5 \\
\hline 119. & Cabang/ranting pada individu yang sama & 52 & 0 & 52 & 53 & 52 & 1 & 98.1 \\
\hline 120. & Ficus ribes & 43 & 24 & 19 & 66 & 64 & 2 & 42.2 \\
\hline 121. & Cabang/ranting pada individu yang sama & 38 & 0 & 38 & 36 & 35 & 1 & 97.4 \\
\hline 122. & Ficus rubra Vahl. & 52 & 34 & 18 & 44 & 44 & 0 & 34.7 \\
\hline 123. & Ficus variegata Blume & 70 & 0 & 70 & 71 & 71 & 0 & 100 \\
\hline 124. & Cabang/ranting pada individu yang sama & 91 & 0 & 91 & 89 & 87 & 2 & 97.8 \\
\hline 125. & Cabang/ranting pada individu yang sama & 55 & 39 & 16 & 56 & 55 & 1 & 28.6 \\
\hline 126. & Cabang/ranting pada individu yang sama & 39 & 32 & 7 & 41 & 40 & 1 & 17.5 \\
\hline 127. & Ficus sinuata Thunb. & 43 & 0 & 43 & 45 & 45 & 0 & 100 \\
\hline 128. & Cabang/ranting pada individu yang sama & 55 & 44 & 11 & 54 & 53 & 1 & 19.6 \\
\hline 129. & Cabang/ranting pada individu yang sama & 32 & 0 & 32 & 33 & 32 & 1 & 97.0 \\
\hline 130. & Ficus obscura Blume & 82 & 71 & 11 & 82 & 81 & 1 & 13.2 \\
\hline 131. & Cabang/ranting pada individu yang sama & 70 & 0 & 70 & 68 & 67 & 1 & 98.6 \\
\hline 132. & Ficus obscura & 72 & 62 & 10 & 70 & 70 & 0 & 13.9 \\
\hline 133. & Cabang/ranting pada individu yang sama & 62 & 52 & 10 & 64 & 63 & 1 & 15.9 \\
\hline 134. & Cabang/ranting pada individu yang sama & 49 & 0 & 49 & 47 & 46 & 1 & 98.0 \\
\hline 135. & Cabang/ranting pada individu yang sama & 66 & 60 & 6 & 68 & 67 & 1 & 8.9 \\
\hline 136. & Cabang/ranting pada individu yang sama & 27 & 26 & 1 & 26 & 25 & 1 & 3.6 \\
\hline 137. & Cabang/ranting pada individu yang sama & 33 & 0 & 33 & 34 & 33 & 1 & 97.0 \\
\hline 138. & Morus nigra L. & 35 & 27 & 8 & 36 & 36 & 0 & 22.8 \\
\hline
\end{tabular}




\begin{tabular}{|c|c|c|c|c|c|c|c|c|}
\hline \multirow{2}{*}{ No. } & \multirow{2}{*}{$\begin{array}{l}\text { Cabang/ranting jenis dan suku tumbuhan } \\
\text { yang diparasiti benalu } D \text {. pentandra }\end{array}$} & \multicolumn{3}{|c|}{$\begin{array}{l}\text { Cabang/ranting terparasiti } \\
(\mathrm{mm})\end{array}$} & \multicolumn{3}{|c|}{$\begin{array}{c}\text { Cabang/ranting bebas } \\
\text { parasit }(\mathrm{mm})\end{array}$} & \multirow{2}{*}{$\begin{array}{l}\text { NK } \\
(\%)\end{array}$} \\
\hline & & $\mathrm{P}$ & $\mathrm{D}$ & P-D & $\mathrm{P} 1$ & D1 & P1-D1 & \\
\hline 139. & Cabang/ranting pada individu yang sama & 28 & 20 & 8 & 27 & 26 & 1 & 27.6 \\
\hline 140. & Morus nigra & 61 & 59 & 2 & 62 & 60 & 2 & 3.2 \\
\hline 141. & Cabang/ranting pada individu yang sama & 62 & 47 & 15 & 60 & 59 & 1 & 23.9 \\
\hline 142. & Cabang/ranting pada individu yang sama & 49 & 0 & 49 & 47 & 45 & 2 & 96.1 \\
\hline 143. & Cabang/ranting pada individu yang sama & 36 & 33 & 3 & 37 & 36 & 1 & 8.1 \\
\hline 144. & Cabang/ranting pada individu yang sama & 44 & 0 & 44 & 44 & 43 & 1 & 97.8 \\
\hline$X X I$ & MYRICACEAE & & & & & & & \\
\hline 145. & Myrica rubra Sieb. \& Zucc. & 68 & 0 & 68 & 69 & 68 & 1 & 98.5 \\
\hline 146. & Cabang/ranting pada individu yang sama & 48 & 0 & 48 & 47 & 46 & 1 & 97.9 \\
\hline 147. & Cabang/ranting pada individu yang sama & 94 & 66 & 28 & 90 & 89 & 1 & 29.5 \\
\hline 148. & Cabang/ranting pada individu yang sama & 52 & 50 & 2 & 51 & 51 & 0 & 3.8 \\
\hline 149. & Cabang/ranting pada individu yang sama & 48 & 41 & 7 & 45 & 44 & 1 & 97.8 \\
\hline 150. & Myrica rubra & 34 & 33 & 1 & 33 & 32 & 1 & 2.8 \\
\hline 151. & Cabang/ranting pada individu yang sama & 49 & 47 & 2 & 50 & 49 & 1 & 4.0 \\
\hline 152. & Cabang/ranting pada individu yang sama & 46 & 43 & 3 & 44 & 43 & 1 & 6.4 \\
\hline 153. & Cabang/ranting pada individu yang sama & 36 & 34 & 2 & 38 & 37 & 1 & 5.4 \\
\hline 154. & Myrica rubra & 55 & 0 & 55 & 62 & 60 & 2 & 96.5 \\
\hline 155. & Cabang/ranting pada individu yang sama & 80 & 58 & 22 & 77 & 76 & 1 & 27.2 \\
\hline 156. & Cabang/ranting pada individu yang sama & 63 & 44 & 19 & 60 & 58 & 2 & 29.2 \\
\hline XXII & MYRTACEAE & & & & & & & \\
\hline 157. & Callistemon citrinus (Curtis) Stapf. & 22 & 16 & 6 & 30 & 30 & 0 & 27.3 \\
\hline 158. & Cabang/ranting pada individu yang sama & 30 & 18 & 12 & 31 & 30 & 1 & 38.7 \\
\hline 159. & Cabang/ranting pada individu yang sama & 25 & 0 & 25 & 22 & 22 & 0 & 100 \\
\hline 160. & Cabang/ranting pada individu yang sama & 43 & 0 & 43 & 40 & 39 & 1 & 97.3 \\
\hline 161. & Callistemon citrinus & 19 & 10 & 9 & 67 & 66 & 1 & 45.0 \\
\hline 162. & Cabang/ranting pada individu yang sama & 97 & 67 & 30 & 99 & 97 & 2 & 30.3 \\
\hline 163. & Cabang/ranting pada individu yang sama & 66 & 0 & 66 & 63 & 62 & 1 & 98.5 \\
\hline 164. & Cabang/ranting pada individu yang sama & 32 & 0 & 32 & 29 & 28 & 1 & 97.0 \\
\hline 165. & Callistemon citrinus & 53 & 46 & 7 & 60 & 58 & 2 & 12.7 \\
\hline 166. & Cabang/ranting pada individu yang sama & 34 & 30 & 4 & 36 & 35 & 1 & 11.4 \\
\hline 167. & Cabang/ranting pada individu yang sama & 26 & 16 & 10 & 23 & 22 & 1 & 37.0 \\
\hline 168. & Cabang/ranting pada individu yang sama & 24 & 21 & 3 & 26 & 25 & 1 & 12.0 \\
\hline 169. & Cabang/ranting pada individu yang sama & 34 & 20 & 14 & 33 & 32 & 1 & 40.0 \\
\hline 170. & Callistemon polandii F.M. Bailey & 43 & 0 & 43 & 40 & 39 & 1 & 97.8 \\
\hline 171. & Cabang/ranting pada individu yang sama & 29 & 26 & 3 & 31 & 31 & 0 & 10.3 \\
\hline 172. & Cabang/ranting pada individu yang sama & 47 & 24 & 23 & 44 & 43 & 1 & 47.9 \\
\hline 173. & Cabang/ranting pada individu yang sama & 69 & 0 & 69 & 66 & 66 & 0 & 100 \\
\hline 174. & Cabang/ranting pada individu yang sama & 44 & 0 & 44 & 41 & 40 & 1 & 97.8 \\
\hline 175. & Eugenia arnottiana Wight. & 34 & 0 & 34 & 47 & 47 & 0 & 100 \\
\hline 176. & Cabang/ranting pada individu yang sama & 85 & 81 & 4 & 83 & 82 & 1 & 4.6 \\
\hline 177. & Cabang/ranting pada individu yang sama & 81 & 51 & 30 & 77 & 76 & 1 & 36.6 \\
\hline 178. & Leptospermum citratum Challinor & 38 & 0 & 38 & 50 & 50 & 0 & 100 \\
\hline 179. & Cabang/ranting pada individu yang sama & 44 & 43 & 1 & 45 & 44 & 1 & 2.2 \\
\hline 180. & Cabang/ranting pada individu yang sama & 29 & 23 & 6 & 26 & 25 & 1 & 20.0 \\
\hline 181. & Cabang/ranting pada individu yang sama & 24 & 0 & 24 & 25 & 24 & 1 & 96.0 \\
\hline 182. & Cabang/ranting pada individu yang sama & 59 & 47 & 12 & 57 & 57 & 0 & 20.3 \\
\hline 183. & Cabang/ranting pada individu yang sama & 83 & 59 & 24 & 81 & 80 & 1 & 28.6 \\
\hline 184. & Cabang/ranting pada individu yang sama & 79 & 75 & 4 & 80 & 79 & 1 & 5.0 \\
\hline 185. & Melaleuca liniariifolia Sm. var. trichystachys & 26 & 23 & 3 & 27 & 27 & 0 & 11.5 \\
\hline
\end{tabular}




\begin{tabular}{|c|c|c|c|c|c|c|c|c|}
\hline \multirow{2}{*}{ No. } & \multirow{2}{*}{$\begin{array}{l}\text { Cabang/ranting jenis dan suku tumbuhan } \\
\text { yang diparasiti benalu } D \text {. pentandra }\end{array}$} & \multicolumn{3}{|c|}{$\begin{array}{l}\text { Cabang/ranting terparasiti } \\
(\mathrm{mm})\end{array}$} & \multicolumn{3}{|c|}{$\begin{array}{c}\text { Cabang/ranting bebas } \\
\text { parasit }(\mathrm{mm})\end{array}$} & \multirow{2}{*}{$\begin{array}{l}\text { NK } \\
(\%)\end{array}$} \\
\hline & & $\mathrm{P}$ & $\mathrm{D}$ & P-D & P1 & D1 & P1-D1 & \\
\hline 186. & Cabang/ranting pada individu yang sama & 22 & 21 & 1 & 20 & 19 & 1 & 4.3 \\
\hline 187. & Syzygium aqueum Alston & 83 & 0 & 83 & 84 & 83 & 1 & 98.8 \\
\hline 188. & Cabang/ranting pada individu yang sama & 76 & 0 & 76 & 75 & 74 & 1 & 98.7 \\
\hline 189. & Cabang/ranting pada individu yang sama & 71 & 0 & 71 & 70 & 70 & 0 & 100 \\
\hline 190. & Cabang/ranting pada individu yang sama & 57 & 0 & 57 & 56 & 55 & 1 & 98.3 \\
\hline 191. & Cabang/ranting pada individu yang sama & 50 & 0 & 50 & 48 & 47 & 1 & 98.0 \\
\hline 192. & Syzygium pycnanthum Merr. \& Perry & 47 & 0 & 47 & 53 & 53 & 0 & 100 \\
\hline 193. & Syzygium racemosum (Blume) DC. & 52 & 0 & 52 & 67 & 67 & 0 & 100 \\
\hline 194. & Cabang/ranting pada individu yang sama & 54 & 53 & 1 & 57 & 56 & 1 & 1.8 \\
\hline 195. & Cabang/ranting pada individu yang sama & 80 & 52 & 28 & 78 & 77 & 1 & 34.6 \\
\hline 196. & Cabang/ranting pada individu yang sama & 60 & 0 & 60 & 58 & 57 & 1 & 98.4 \\
\hline 197. & Cabang/ranting pada individu yang sama & 66 & 0 & 66 & 54 & 54 & 0 & 100 \\
\hline 198. & Syzygium racemosum & 34 & 0 & 34 & 33 & 32 & 1 & 97.1 \\
\hline 199. & Syzygium racemosum & 28 & 0 & 28 & 28 & 28 & 0 & 100 \\
\hline 200. & Syzygium racemosum & 57 & 0 & 57 & 55 & 54 & 1 & 98.3 \\
\hline 201. & Cabang/ranting pada individu yang sama & 50 & 0 & 50 & 51 & 49 & 2 & 96.1 \\
\hline 202. & Syzygium racemosum & 34 & 0 & 34 & 38 & 37 & 1 & 97.1 \\
\hline 203. & Syzygium racemosum & 45 & 29 & 16 & 44 & 44 & 0 & 35.5 \\
\hline 204. & Syzygium racemosum & 40 & 29 & 13 & 43 & 43 & 0 & 32.5 \\
\hline 205. & Cabang/ranting pada individu yang sama & 33 & 26 & 7 & 31 & 30 & 1 & 20.6 \\
\hline 206. & Cabang/ranting pada individu yang sama & 34 & 27 & 7 & 35 & 33 & 2 & 19.4 \\
\hline 207. & Cabang/ranting pada individu yang sama & 35 & 0 & 35 & 37 & 36 & 1 & 97.2 \\
\hline XXIII & OLEACEAE & & & & & & & \\
\hline 208. & Ligustrum lucidum W.T. Aiton & 65 & 63 & 2 & 55 & 54 & 1 & 3.0 \\
\hline 209. & Cabang/ranting pada individu yang sama & 63 & 52 & 11 & 63 & 62 & 1 & 17.2 \\
\hline 210. & Cabang/ranting pada individu yang sama & 51 & 46 & 5 & 50 & 49 & 1 & 9.6 \\
\hline XXIV & PINACEAE & & & & & & & \\
\hline 211. & Pinus parviflora Sieber \& Zucc. & 44 & 28 & 16 & 68 & 66 & 2 & 34.8 \\
\hline$x X V$ & PROTEACEAE & & & & & & & \\
\hline 212. & Macadamia ternifolia F.Muell. cv. Kokensos & 31 & 26 & 5 & 29 & 29 & 0 & 16,1 \\
\hline 213. & Cabang/ranting pada individu yang sama & 39 & 30 & 9 & 37 & 36 & 1 & 22.5 \\
\hline 214. & Cabang/ranting pada individu yang sama & 34 & 21 & 13 & 32 & 32 & 0 & 38.2 \\
\hline 215. & Cabang/ranting pada individu yang sama & 28 & 0 & 28 & 29 & 29 & 0 & 100 \\
\hline 216. & Cabang/ranting pada individu yang sama & 34 & 20 & 14 & 33 & 32 & 1 & 40.0 \\
\hline $\mathrm{XXVI}$ & ROSACEAE & & & & & & & \\
\hline 217. & Cotoneaster pannosa Franch. & 25 & 19 & 6 & 45 & 44 & 1 & 23.1 \\
\hline 218. & Crataegus pyracantha Medic. & 50 & 0 & 50 & 50 & 50 & 0 & 100 \\
\hline 219. & Cabang/ranting pada individu yang sama & 28 & 0 & 28 & 28 & 27 & 1 & 96.5 \\
\hline 220. & Cabang/ranting pada individu yang sama & 38 & 31 & 7 & 35 & 34 & 1 & 17.9 \\
\hline 221. & Cabang/ranting pada individu yang sama & 21 & 20 & 1 & 22 & 21 & 1 & 4.5 \\
\hline 222. & Cabang/ranting pada individu yang sama & 22 & 0 & 22 & 20 & 18 & 2 & 91.7 \\
\hline 223. & Poterium sanguisorba $\mathrm{L}$. & 38 & 27 & 11 & 52 & 52 & 0 & 28.9 \\
\hline 224. & Cabang/ranting pada individu yang sama & 19 & 18 & 1 & 17 & 16 & 1 & 5,0 \\
\hline 225. & Cabang/ranting pada individu yang sama & 14 & 0 & 14 & 16 & 15 & 1 & 93.3 \\
\hline
\end{tabular}




\begin{tabular}{|c|c|c|c|c|c|c|c|c|}
\hline \multirow{2}{*}{ No. } & \multirow{2}{*}{$\begin{array}{l}\text { Cabang/ranting jenis dan suku tumbuhan } \\
\text { yang diparasiti benalu } D \text {. pentandra }\end{array}$} & \multicolumn{3}{|c|}{$\begin{array}{l}\text { Cabang/ranting terparasiti } \\
(\mathrm{mm})\end{array}$} & \multicolumn{3}{|c|}{$\begin{array}{c}\text { Cabang/ranting bebas } \\
\text { parasit }(\mathrm{mm})\end{array}$} & \multirow{2}{*}{$\begin{array}{l}\text { NK } \\
(\%)\end{array}$} \\
\hline & & $\mathrm{P}$ & $\mathrm{D}$ & $P-D$ & $\mathrm{P} 1$ & D1 & P1-D1 & \\
\hline 226. & Poterium sanguisorba & 24 & 19 & 5 & 25 & 24 & 1 & 20.0 \\
\hline 227. & Prunus cerasoides D. Don. & 44 & 42 & 2 & 46 & 45 & 1 & 4.4 \\
\hline 228. & Prunus cerasoides & 44 & 0 & 44 & 46 & 44 & 2 & 95.6 \\
\hline 229. & Prunus cerasoides & 48 & 40 & 8 & 52 & 52 & 0 & 16.7 \\
\hline 230. & Cabang/ranting pada individu yang sama & 24 & 10 & 14 & 26 & 25 & 1 & 56.0 \\
\hline 231. & Cabang/ranting pada individu yang sama & 62 & 24 & 38 & 59 & 58 & 2 & 59.4 \\
\hline 232. & Cabang/ranting pada individu yang sama & 31 & 14 & 17 & 30 & 29 & 1 & 53.1 \\
\hline 233. & Prunus cerasoides & 39 & 0 & 39 & 44 & 44 & 0 & 100 \\
\hline 234. & Prunus cerasoides & 43 & 0 & 43 & 44 & 44 & 0 & 100 \\
\hline 235. & Pyracantha crenato-serrata (Hance) Rehd. & 88 & 54 & 34 & 91 & 90 & 1 & 38.2 \\
\hline 236. & Cabang/ranting pada individu yang sama & 55 & 42 & 13 & 55 & 49 & 1 & 23.2 \\
\hline 237. & Cabang/ranting pada individu yang sama & 79 & 69 & 10 & 80 & 79 & 1 & 12.5 \\
\hline 238. & Cabang/ranting pada individu yang sama & 68 & 27 & 41 & 66 & 64 & 2 & 58.6 \\
\hline 239. & Cabang/ranting pada individu yang sama & 58 & 49 & 9 & 56 & 55 & 1 & 15.2 \\
\hline 240. & Pyracantha crenato-serrata & 74 & 53 & 21 & 86 & 85 & 1 & 28.0 \\
\hline 241. & Cabang/ranting pada individu yang sama & 53 & 52 & 1 & 51 & 50 & 0 & 1.9 \\
\hline 242. & Cabang/ranting pada individu yang sama & 52 & 50 & 2 & 49 & 48 & 1 & 3.8 \\
\hline 243. & Pyracantha fortuneana (Maxim) Lig & 30 & 0 & 30 & 45 & 45 & 0 & 100 \\
\hline 244. & Cabang/ranting pada individu yang sama & 53 & 52 & 1 & 51 & 50 & 1 & 1.8 \\
\hline 245 & Cabang/ranting pada individu yang sama & 43 & 0 & 43 & 45 & 44 & 1 & 97.8 \\
\hline 246. & Rhaphiolepis indica (L.) Lindl. ex Ker. & 23 & 21 & 2 & 26 & 26 & 0 & 8.7 \\
\hline 247. & Cabang/ranting pada individu yang sama & 22 & 0 & 22 & 24 & 22 & 2 & 91.7 \\
\hline 248. & Cabang/ranting pada individu yang sama & 21 & 0 & 21 & 22 & 21 & 1 & 95.4 \\
\hline 249. & Cabang/ranting pada individu yang sama & 19 & 14 & 5 & 20 & 19 & 1 & 25.0 \\
\hline XXVII & RUBIACEAE & & & & & & & \\
\hline 250. & Hamelia sphaerocarpa Ruiz \& Pavon & 51 & 49 & 2 & 49 & 49 & 0 & 3.9 \\
\hline 251. & Cabang/ranting pada individu yang sama & 56 & 44 & 12 & 55 & 55 & 0 & 21.4 \\
\hline 252. & Neonauclea lanceolata (Blume) Merr. & 50 & 29 & 21 & 44 & 44 & 0 & 42.0 \\
\hline XXVIII & RUTACEAE & & & & & & & \\
\hline 253. & Acronychia laurifolia Blume & 79 & 72 & 7 & 85 & 85 & 0 & 8.9 \\
\hline 254. & Cabang/ranting pada individu yang sama & 85 & 80 & 5 & 86 & 86 & 0 & 5.9 \\
\hline 255. & Cabang/ranting pada individu yang sama & 86 & 0 & 86 & 83 & 81 & 2 & 97.7 \\
\hline 256. & Cabang/ranting pada individu yang sama & 48 & 42 & 6 & 47 & 46 & 1 & 12.2 \\
\hline 257. & Cabang/ranting pada individu yang sama & 42 & 36 & 6 & 42 & 42 & 0 & 14.3 \\
\hline 258. & Cabang/ranting pada individu yang sama & 35 & 0 & 35 & 37 & 36 & 1 & 97.2 \\
\hline 259. & Citrus grandis (L.) Osbeck. & 57 & 54 & 3 & 69 & 69 & 0 & 5.3 \\
\hline 260. & Cabang/ranting pada individu yang sama & 51 & 21 & 30 & 53 & 52 & 1 & 57.7 \\
\hline 261. & Cabang/ranting pada individu yang sama & 63 & 54 & 9 & 63 & 62 & 1 & 14.1 \\
\hline 262. & Cabang/ranting pada individu yang sama & 39 & 0 & 39 & 36 & 35 & 1 & 97.5 \\
\hline 263. & Cabang/ranting pada individu yang sama & 79 & 68 & 11 & 77 & 76 & 1 & 13.75 \\
\hline 264. & Cabang/ranting pada individu yang sama & 64 & 0 & 64 & 60 & 59 & 1 & 98.5 \\
\hline 265. & Melicope denhamii (Seem.) T.G.Hartley & 39 & 27 & 12 & 40 & 39 & 1 & 30.0 \\
\hline 266. & Cabang/ranting pada individu yang sama & 54 & 44 & 10 & 51 & 49 & 2 & 17.8 \\
\hline 267. & Cabang/ranting pada individu yang sama & 77 & 0 & 77 & 71 & 70 & 1 & 98.7 \\
\hline 268. & Cabang/ranting pada individu yang sama & 21 & 0 & 21 & 20 & 18 & 2 & 87.5 \\
\hline
\end{tabular}




\begin{tabular}{|c|c|c|c|c|c|c|c|c|}
\hline \multirow{2}{*}{ No. } & \multirow{2}{*}{$\begin{array}{l}\text { Cabang/ranting jenis dan suku tumbuhan } \\
\text { yang diparasiti benalu } D \text {. pentandra }\end{array}$} & \multicolumn{3}{|c|}{$\begin{array}{l}\text { Cabang/ranting terparasiti } \\
(\mathrm{mm})\end{array}$} & \multicolumn{3}{|c|}{$\begin{array}{c}\text { Cabang/ranting bebas } \\
\text { parasit }(\mathrm{mm})\end{array}$} & \multirow{2}{*}{$\begin{array}{l}\text { NK } \\
(\%)\end{array}$} \\
\hline & & $\mathrm{P}$ & $\mathrm{D}$ & P-D & $\mathrm{P} 1$ & D1 & P1-D1 & \\
\hline 269. & Cabang/ranting pada individu yang sama & 44 & 25 & 19 & 41 & 41 & 0 & 43.2 \\
\hline 270. & Cabang/ranting pada individu yang sama & 47 & 0 & 47 & 49 & 48 & 1 & 97.9 \\
\hline XXIX & SALICACEAE & & & & & & & \\
\hline 271. & Salix babylonica $\mathrm{L}$. & 60 & 56 & 4 & 55 & 53 & 2 & 6.4 \\
\hline 272. & Cabang/ranting pada individu yang sama & 79 & 78 & 1 & 80 & 79 & 1 & 1.2 \\
\hline 273. & Cabang/ranting pada individu yang sama & 67 & 60 & 7 & 66 & 65 & 1 & 10.3 \\
\hline 274. & Salix babylonica & 27 & 25 & 2 & 25 & 23 & 2 & 6.9 \\
\hline 275. & Cabang/ranting pada individu yang sama & 34 & 31 & 3 & 35 & 34 & 1 & 8.6 \\
\hline 276. & Cabang/ranting pada individu yang sama & 40 & 36 & 4 & 42 & 43 & 1 & 9.7 \\
\hline$X X X$ & SCROPHULARIACEAE & & & & & & & \\
\hline 277. & Paulownia taiwaniana T.W.Hu \& H.J. Chang & 37 & 12 & 25 & 82 & 81 & 1 & 13.1 \\
\hline XXXI & SOLANACEAE & & & & & & & \\
\hline 278. & Brunfelsia australis Benth. & 34 & 31 & 3 & 34 & 34 & 0 & 8.8 \\
\hline 279. & Cabang/ranting pada individu yang sama & 18 & 15 & 3 & 19 & 18 & 1 & 15.8 \\
\hline 280. & Cabang/ranting pada individu yang sama & 24 & 21 & 3 & 22 & 22 & 0 & 12.5 \\
\hline 281. & Cabang/ranting pada individu yang sama & 21 & 20 & 1 & 23 & 22 & 1 & 4.5 \\
\hline 282. & Cabang/ranting pada individu yang sama & 19 & 17 & 2 & 20 & 19 & 1 & 10.0 \\
\hline XXXII & STERCULIACEAE & & & & & & & \\
\hline 283. & Pterospermum javanicum Junghuhn & 35 & 23 & 12 & 52 & 51 & 1 & 33.3 \\
\hline 284. & Cabang/ranting pada individu yang sama & 79 & 59 & 20 & 77 & 76 & 1 & 25.0 \\
\hline 285. & Cabang/ranting pada individu yang sama & 33 & 29 & 4 & 35 & 34 & 1 & 11.8 \\
\hline XXXIII & TAXODIACEAE & & & & & & & \\
\hline 286. & Cryptomeria japonica (L.) D. Don. & 86 & 75 & 11 & 11 & 10 & 1 & 12.6 \\
\hline 287. & Cabang/ranting pada individu yang sama & 76 & 73 & 3 & 75 & 74 & 1 & 3.9 \\
\hline 288. & Cabang/ranting pada individu yang sama & 71 & 52 & 19 & 70 & 70 & 0 & 26.8 \\
\hline 289. & Cabang/ranting pada individu yang sama & 51 & 45 & 6 & 49 & 47 & 2 & 11.3 \\
\hline 290. & Cryptomeria japonica & 81 & 71 & 10 & 83 & 82 & 1 & 12.2 \\
\hline 291. & Cabang/ranting pada individu yang sama & 72 & 69 & 3 & 70 & 69 & 1 & 4.1 \\
\hline 292. & Cabang/ranting pada individu yang sama & 20 & 19 & 1 & 21 & 20 & 1 & 4.8 \\
\hline 293. & Taxodium mucronatum Ten. & 35 & 0 & 35 & 34 & 33 & 1 & 97.2 \\
\hline XXXIV & THEACEAE & & & & & & & \\
\hline 294. & Camellia japonica L. & 34 & 27 & 7 & 40 & 38 & 2 & 19.4 \\
\hline 295. & Cabang/ranting pada individu yang sama & 49 & 33 & 16 & 45 & 43 & 2 & 31.4 \\
\hline 296. & Cabang/ranting pada individu yang sama & 30 & 0 & 30 & 27 & 26 & 1 & 96.8 \\
\hline$X X X V$ & ULMACEAE & & & & & & & \\
\hline 297. & Celtis sinensis Pers. & 28 & 24 & 4 & 31 & 29 & 2 & 13.3 \\
\hline XXXVI & URTICACEAE & & & & & & & \\
\hline 298. & Villebrunea scabra Wedd. & 30 & 27 & 3 & 30 & 30 & 0 & 10.0 \\
\hline 299. & Cabang/ranting pada individu yang sama & 29 & 20 & 9 & 30 & 29 & 1 & 30.0 \\
\hline
\end{tabular}

Annonaceae (66,7\%), Elaeocarpaceae $(66,7 \%)$, dan Myrtaceae (50\%).

Pemarasitan oleh benalu secara umum memperlihatkan terjadinya gangguan pada tumbuhan inang yang diparasitinya. Penelitian sebelumnya yang dilakukan di Kebun Raya Purwodadi, Jawa Timur (Sunaryo at al, 2006) dan Kebun Raya Bali (Sunaryo et al, 2007) menunjukkan adanya gangguan bahkan kerusakan morfologi tumbuhan koleksi yang disebabkan oleh pemarasitan beberapa jenis benalu. Gangguan 
ataupun kerusakan yang utama terjadi pada bagian cabang/ranting yang diparasiti benalu. Hal yang tidak jauh berbeda ditunjukkan dari hasil penelitian yang dilakukan di KR Cibodas, Jawa Barat ini.

Tumbuhan koleksi KR Cibodas yang banyak diparasiti benalu $D$. pentandra adalah jenis Ficus (Moraceae). Ada lima jenis Ficus koleksi KR Cibodas yang diparasiti benalu $D$. pentandra. Sedangkan individu yang paling banyak diparasiti adalah Syzygium racemosum (Myrtaceae). Diperkirakan terdapat beberapa faktor berkaitan dengan pemarasitan benalu terhadap jenis-jenis tumbuhan inangnya. Salah satu faktor di antaranya kemungkinan adalah tebal/tipisnya ataupun keras lunaknya bagian kulit cabang/ranting tumbuhan inang yang diparasitinya. Beberapa jenis Ficus maupun Syzygium memiliki kulit cabang/ranting yang relatif tipis dan lunak. Kulit cabang/ranting tumbuhan inang yang tipis dan lunak diperkirakan lebih mempermudah benalu pada awal-awal pertumbuhannya untuk mampu menginvasi bagian kayu yang lebih dalam. Sedangkan kulit cabang/ranting yang tebal dan keras (mis. jenis mahoni) akan menghambat secara fisik bagi pertumbuhan awal benalu, sehingga cadangan makanan yang tersedia habis terlebih dahulu sebelum haustorium, sebagai alat kotak benalu dengan tumbuhan inangnya, mencapai bagian-bagian kayu untuk pertumbuhan selanjutnya.

Dari hasil pengamatan ini disarankan bahwa keberadaan benalu $D$. pentandra di Kebun Raya Cibodas hendaknya selalu berada dalam pemantauan. Dalam kondisi seperti tersebut di atas maka pengendalian terhadap jenis benalu ini sudah harus dilakukan. Pengendalian benalu yang saat ini baru bisa dilakukan adalah dengan pemangkasan terhadap cabang/ranting yang diparasitinya, terutama benalu yang sudah berada pada fase generatif.

\section{KESIMPULAN}

Benalu Dendrophthoe pentandra diketahui memarasiti sebanyak 67 jenis tumbuhan koleksi Kebun Raya Cibodas, yang jenis-jenisnya terbagi kedalam 36 suku. Jenis-jenis yang paling banyak diparasiti adalah dari marga Ficus (Moraceae), sedangkan individu yang paling banyak diparasiti adalah jenis Syzygium racemosus (Myrtaceae). Pengukuran gangguan pada 299 cabang/ranting terlihat adanya kerusakan- kerusakan terutama pada cabang/ranting bagian distal tumbuhan yang diparasiti benalu $D$. pentandra. Semakin besar selisih antara bagian proksimal dengan bagian distal cabang/ranting yang diparasiti benalu, maka akan semakin besar pula nilai kerusakan pada cabang/ranting tersebut.

\section{UCAPAN TERIMA KASIH}

Terimakasih disampaikan kepada Kepala Kebun Raya Cibodas yang telah memberikan ijin dan penyediaan fasilitas selama dilakukannya penelitian ini. Terima kasih juga kami sampaikan kepada Drs. Tahan Uji yang telah membantu dalam identifikasi spesimen tumbuhan.

\section{DAFTAR PUSTAKA}

Backer, C.A. \& Bakhuizen van den Brink. 1965. Flora of Java. Vol. 2. Netherlands: Noordhoff Groningen.

Balgooy van, M.M.J. 1987. Collecting. In : Vogel (ed.). Mannual of Herbarium Taxonomy. Theory and Practice. Unesco.

Barlow, B.A. 1967. Loranthaceae. In :C. Kalkman, D.W. Kirkup, H.P. Nootebom, P.F. Stevens, W.J.J.O. de Wilde (eds.). Flora Malesiana. Series I, vol. 13. Rijksherbarium/Hortus Botanicus, The Netherlands.

Immamudin, H., Suryaman, N., Sukatman, A. \& Hidayat, A. 2005. An alphabetical list of plant cultivated in the Cibodas Botanic Garden. Cibodas Botanic Garden.

Rugayah, Widjaja, E.A. \& Praptiwi. 2004. Pedoman pengumpulan data keanekaragaman flora. Pusat Penelitian Biologi - LIPI, Bogor.

Sunaryo, 1998. Identifikasi kerusakan tumbuhan inang oleh parasit Dendrophthoe pentandra (L.) Miq. (Loranthaceae): Sebuah studi kasus di Tahura Bengkulu. Berita Biologi 4 (2 \& 3): $80-85$

Sunaryo, Rachman, E. \& Uji, T. 2006. Kerusakan morfologi tumbuhan koleksi Kebun Raya Purwodadi oleh benalu (Loranthaceae dan Viscaceae). Berita Biologi 8(2): 129 139.

Sunaryo, Rachman, E. \& Uji, T. 2007. Identifikasi Kerusakan tumbuhan di Kebun Raya Bali oleh benalu. J. Tek. Ling. 8(2): 172-180.

Sunaryo. Menghitung Nilai kerusakan tumbuhan inang akibat pemarasitan benalu. Berita Biologi (dalam editing).

Uji, T., Sunaryo, \& Rachman, E. 2006. Keanekaragaman jenis benalu Parasit pada tanaman koleksi di Kebun Raya Purwodadi, Jawa Timur. J. Tek. Ling. Edisi Khusus 223 231

Uji, T. \& Sunaryo. Keragaman dan Penyebaran Benalu pada Tanaman Koleksi di Kebun Raya Cibodas, Jawa Barat. Biota (dalam editing).

Valkenburg van J.L.C.H. 2003. Dendrophthoe. In: R.H.M.J. Lemmens and N. Bunyapraphatsara (eds.). Medicinal and poisonous plants 3. PROSEA. Backhuys Publisher, Leiden.

Sunaryo. Menghitung Nilai kerusakan tumbuhan inang akibat pemarasitan benalu. Berita Biologi (dalam editing).

Uji, T., Sunaryo, \& Rachman, E. 2006. Keanekaragaman jenis benalu Parasit pada tanaman koleksi di Kebun Raya Purwodadi, Jawa Timur. J. Tek. Ling. Edisi Khusus 223 231.

Uji, T. \& Sunaryo. Keragaman dan Penyebaran Benalu pada Tanaman Koleksi di Kebun Raya Cibodas, Jawa Barat. Biota (dalam editing).

Valkenburg van J.L.C.H. 2003. Dendrophthoe. In: R.H.M.J. Lemmens and N. Bunyapraphatsara (eds.). Medicinal and poisonous plants 3. PROSEA. Backhuys Publisher, Leiden. 